NASA Technical Memorandum 89883

AIAA-87-9318

\title{
Effect of Storage and LEO Cycling on Manufacturing Technology IPV Nickel-Hydrogen Cells
}

\author{
(NASA-TA-89883) EFFECT OF STCEAGE AHD LEO \\ CICLING CN HANOEACIORIHG TECBACICGY IPV \\ RICKEL-HYDROGEN CELLS (NASA) 9 p AVAil: \\ NTIS HC AO2/BR AOI \\ CSCL $10 \mathrm{C}$
}

N87-22308

Unclas

B $1 / 44 \quad 0072114$

John J. Smithrick

Lewis Research Center

Cleveland, Ohio

Prepared for the

22nd Intersociety Energy Conversion Engineering Conference cosponsored by the AIAA, ANS, ASME, SAE, IEEE, ACS, and AIChE Philadelphia, Pennsylvania, August 10-14, 1987

\section{NMSA}


John J. Smithrick

National Aeronautics and Space Administration

Lewis Research Center

Cleveland, Ohio 44135

\section{ABSTRACT}

Yardney Manufacturing Technology (MANTECH) $50 \mathrm{~A}-\mathrm{hr}$ space weight individual pressure vessel nickel-hydrogen cells were evaluated. This consisted of investigating: (1) the effect of storage and (2) charge/discharge cycling on cell performance. For the storage test the cells were precharged with hydrogen, by the manufacturer, to a pressure of 14.5 psia. After undergoing activation and acceptance tests, the cells were discharged at $\mathrm{C} / 10$ rate $(5 \mathrm{~A})$ to $0.1 \mathrm{~V}$ or less. The terminals were then shorted. The cells were shipped to the NASA Lewis Research Center where they were stored at room temperature in the shorted condition for $1 \mathrm{yr}$. After storage, the acceptance tests were repeated at NASA Lewis. A comparison of test results indicate no significant degradation in electrical performance due to 1 yr storage. For the cycle life test the regime was a 90 min low earth orbit at deep depths of discharge ( 80 and 60 percent). At the 80 percent 000 the three cells falled on the average at cycle 741 . Fallure for this test was defined to occur when the cell voltage degraded to $1 \mathrm{~V}$ prior to completion of the $35 \mathrm{~min}$ discharge. The 000 was reduced to $60 \mathrm{per}$ cent. The cycle life test was continued.

\section{INTRODUCTION}

As part of an overall effort to advance the technology of nickel-hydrogen $\left(\mathrm{N}_{1} / \mathrm{H}_{2}\right)$ batteries for possible use in an energy storage system, in low earth orbit (LEO), Yardney Manufacturing Technology (MANTECH) $50 \mathrm{~A}-\mathrm{hr}$ space weight individual pressure vessel (IPV) nickel-hydrogen cells were evaluated. This consisted of investigating the effect of storage and charge/discharge cycling on cell performance. The effect of storage on cell performance is important because nickel-hydrogen batteries could be subjected to storage for extended periods of $t$ ime prior to launch. It has been reported that some nickel-hydrogen batteries degrade in capacity on storage while others do not degrade on storage. 1 Battery cycle $11 \mathrm{fe}$ is important to assess their suitability for specific flight programs. The data base for MANTECH cells is very limited.

In this communtcation the results of storage and cycle life test on Yardney MANTECH $50 \mathrm{~A}-\mathrm{hr}$ space weight IPV nickel-hydrogen ce1ls is reported.

\section{EXPERIMENTAL}

\section{Test Facility}

The test facllity used to cycle life test the nickel-hydrogen cells is 17 lustrated in $\mathrm{Fig} .1$. The facllity design incorporates two main features: safety and versatility. Since the nickel-hydrogen cells are precharged with hydrogen and also generates hydrogen during charge, spectal attention was given to personnel safety. The cells were located on top of the instrumentation cabinets. There were two cells for each cabinet. Each cell was located within a cylindrical shrapnel shield in case of the improbable event of an explosion or rupture of the cell pressure vessel. During a test, the cylindrical shield was purged with nitrogen to create an inert atmosphere. The nitrogen gas, and hydrogen gas if any, would be exhausted from the test laboratory through a hood located above the cells. If the exhaust fan would fall or the nitrogen purge would become interrupted the test would be automatically terminated. A test can also be terminated on a preset upper and/or lower limit of cell voltage, current, pressure, and temperature.

The facility's versatility allows for testing over a wide range of cycle regimes. A geosynchronous earth orbit (GEO) cycle regime can be run in real time using a programmable timer. Various accelerated GEO and low earth orbit cycle regimes can be run using a Texas Instrument timer. The cell discharge current is controlled by an electronic load, which can be varied from 0 to $100 \mathrm{~A}$. The charge current can also be varied in the same range. Test data is printed out locally using a Fluke data collector. Strip chart recorders are used to record cell voltage, current, and pressure as a continuous function of charge and discharge time for selected cycles. A maximum of twelve cells can be tested at the same time.

\section{TEST CELL DESCRIPTION}

The three cells were 50 A-hr capacity space weight IPV nickel-hydrogen cells. They were manufactured by Yardney Electric Corporation (Battery Division) according to specifications directed under the Air Force (WPAB) manufacturing technology contract with Yardney. 2 The cell is illustrated in Fig. 2. It consists of a stack of nickel electrodes, separators, hydrogen electrodes, and gas screens assembled in a non back-to-back electrode configuration. In this configuration electrodes of different types directly face each other. The stack is packaged in a cylindrical pressure vessel. with hemispherical end caps. This is made of incone 1718 and lined with zirconium dioxide which serves as a wall wick. The components are shaped in a "pineapple" slice pattern. The electrodes are connected electrically in parallel. A dual separator, consisting of one layer of asbestos and one layer of zircar, is used. Hence, since a high bubble pressure asbestos separator is used, the oxygen generated at the nickel electrode on charge is directed to the hydrogen electrode on the next unit cell, where it combines chemically to form water. The zircar separators are extended beyond the electrodes to contact the wall wick. Hence electrolyte which leaves the stack during cycling will be wicked back into the stack. The gas screens are polypropylene. The electrolyte is a 31 percent aqueous solution of potassium hydroxide. The nickel electrode consisted of a nickel slurry 
plaque containing a nickel screen substrate, which was electrochemically impregnated by the aqueous Siger/Puglist process. 3 The cells were precharged with hydrogen to a pressure of 14.5 psia.

Measurements and Procedures

For this experiment the quantities measured for each cell at the end of charge and discharge, and their accuracles were: Current ( \pm 0.3 percent). voltage $( \pm 0.5$ percent) pressure $(+1$ percent), and temperature $\left(+1{ }^{\circ} \mathrm{C}\right.$ limit of error). Additional measurements were charged and discharged amperehours ( +0.5 percent) and charge to discharge ampere-hour ratio. Cell current, voltage pressure, and temperature were recorded continuousiy as a function of time, for selected cycles, on a strip chart recorder.

Cell charge and discharge currents were measured across a shunt, using an integrating digital voltmeter. Cell voltage was aiso measured using an integrating digital voltmeter. Cell pressure was measured using a strain gauge located on the cell dome. The temperature was measured using an iron-constantan thermocouple located on the center of the pressure vessel dome. The thermocouple was mounted using a heat sink compound to insure good thermal contact. Charge and discharge capacity was measured using an ampere-hour meter. Charge to discharge ratio (ampere-hour into cell on charge to ampere-hours out on discharge) was calculated from the ampere-hour measurements.

For the storage test the cells were discharged at the $c / 10$ rate $(5 \mathrm{~A})$ to about $0.1 \mathrm{~V}$ or less. Then the cell precharge hydrogen pressure was set by the manufacturer to 0 psig ( 14.5 psia). After und going activation and acceptance test, the celis were once again discharged at the $C / 10$ rate (5 A) to $0.1 \mathrm{~V}$ or less. The terminals were shorted. The cells were shipped to NASA Lewis where they were stored at room temperature in the shorted condition for $1 \mathrm{yr}$. After storage the acceptance test was repeated at NASA Lewis. The tests consisted of measuring the discharge amperehour capacity, and ampere-hour capacity retention.

The discharge capacity was measured after charging the cell at the $\mathrm{C} / 10$ rate $(5 \mathrm{~A})$ for $16 \mathrm{hr}$, followed by a $1 \mathrm{hr}$ open circuit voltage stand. The discharge capacity was measured at the $\mathrm{C} / 2$ rate $(25 \mathrm{~A})$ to $1 \mathrm{~V}$.

The cell charge retention was calculated from measured capacities. The cell was charged for $16 \mathrm{hr}$ at the $\mathrm{c} / 10$ rate, followed by a $72 \mathrm{hr}$ open circuit stand. After the $72 \mathrm{hr}$ the capacity was measured by discharging the cell at the $c / 2$ rate to $1 \mathrm{~V}$, followed by a $\mathrm{C} / 10$ rate discharge to about $0 \mathrm{~V}$. The total ampere-hour capacity was compared to a similar capacity measurement prior to open circuit stand. The cell charge retention was calculated as the ratio of the total capacity after the open circuit stand to the total capacity prior to the open circuit stand. The cell temperature was controlled during this experiment to $20 \pm 3{ }^{\circ} \mathrm{C}$.

For the cycle life test the cells were charge/ discharge cycled to fallure under a $90 \mathrm{~min}$ LEO cycle regime to deep depths of discharge ( 80 and 60 percent). Initially the DOD was set at 80 percent of rated ampere-hour capacity. The cells performed poorly at this D00. They falled on the average at cycle 741. After fallure the cells were reconditioned which consisted of: (1) deep discharge - cells were discharged at $\mathrm{C} / 2$ rate to $1.0 \mathrm{~V}$ then the discharge was continued at $\mathrm{c} / 10$ rate to $0.1 \mathrm{~V}$ or less; and (2) a comblnation of open circuit stand and deep discharge reconditioning. The cells were left on open circult stand for 28 days. Then the cells were deep discharged reconditioned as stated above. After reconditioning the cells were placed back on cycling at 80 percent $D 0 D$. When the cells falled after the second attempt to recondition the $00 D$ was reduced to 60 percent and the cycle test continued. For this test fallure was defined to occur, when the discharge voltage degraded to $1.0 \mathrm{~V}$ during the course of a constant current 35 min discharge. For the first test cycle, the cells were charged for $16 \mathrm{hr}$ at the $\mathrm{C} / 10$ rate followed by discharge at the $1.37 \mathrm{C}$ rate $(68.5 \mathrm{~A})$ for $35 \mathrm{~min}$. Then the norma 180 percent 000 LEO charge/discharge cycling was initiated which consisted of charging the cells at a constant $0.96 \mathrm{C}$ rate $(48 \mathrm{~A})$ for 55 min immediately followed by discharge at a constant $1.37 \mathrm{C}$ rate for $35 \mathrm{~min}$. For the 60 percent DOD test the cells were charged at the $0.72 \mathrm{C}$ rate $(36 \mathrm{~A})$ and discharged at a constant $1.03 \mathrm{C}$ rate $(51.4 \mathrm{~A})$. The charge to discharge ratio was initially set at 1.05 and increased as the cycling progressed to a final value of 1.10 in an attempt to improve cell performance. The charge and discharge rates stated above are for a charge to discharge ratio of 1.10 . During the cycle life test the temperature was controlled to $20 \pm 3{ }^{\circ} \mathrm{C}$.

\section{RESULTS AND DISCUSSION}

Storage test. The effect of storage ( $1 \mathrm{yr}$, terminals shorted) on the capacity of three, $50 \mathrm{~A}$-hr space weight IPV nickel-hydrogen cells is summarized in Fig. 3. The spread in the data indicate there is no significant capacity loss due to the 1 yr storage. This information is relevant to applications where the battery is in planned or unplanned storage (launch delay) for up to $1 \mathrm{yr}$. It is also advantageous to store cells in the shorted condition, since this eliminates the potential hazard associated with high voltage.

The effect of storage on capacity retention of the nickel-hydrogen cells, after a $72 \mathrm{hr}$ open circuit stand is summarized in $\mathrm{Fig}$. 4. The spread in the data indicate no significant difference in capacity due to the 1 yr storage.

The capacity of each cell after the storage was measured at the intended use rate $(1.37 \mathrm{C}=$ 68.5 A) to a $1 \mathrm{~V}$ cut off. The results are shown in Table 1. The average capacity of the three cells was $53 \mathrm{~A}-\mathrm{hr}$.

Cycle test. The cells were cycled at two different deep depths of discharge ( 80 and 60 percent). Initially the cells were cycled at 80 percent $D O D$. At this $D O D$ the performance was poor. The results of the 80 percent DOD test are summarized in Table 2. On the average the cells falled at cycle 741. The fallure was characterized by a degradation of end of discharge voltage to $1 \mathrm{~V}$ prior to the end of the $35 \mathrm{~min}$ discharge. For these cells the 80 percent DOD was apparently too stressful. In an attempt to improve cell performance, the cells were deep discharged and open circuit stand reconditioned. They were placed 
back on cycling at 80 percent 000 ; and once again falled due to low end of discharge voltage. The reconditioning had a very limited beneficial effect. The DOD was reduced to 60 percent and the cycle test continued. At this DOD the performance improved. The cumulative cycle life results $(80+60$ percent $D 0 D)$ for this continuing test are summarized in Table 3 . For cell 1 the $V_{E O D}=$ 1.11 at cycle 2331, for cell 2 the $V_{E O D}=1.11$ at cycle 2470, and for cell 3 the $V_{E O D}=1.11$ at cycle 2468 .

The effect of cycling on the end of discharge voltage for a representative cell is shown in Fig. 5. The cell falled at cycle 750 ( 80 percent $D O D)$. The cycling was continued until the end of discharge voltage reached $0.94 \mathrm{~V}$. The cell was deep discharge reconditioned and the cycling continued at the 80 percent DOD. This reconditioning had only a short term beneficial effect. It was placed on open circuit stand for 28 days followed by a deep discharge recondition, and placed back on cycling at the 80 percent DOD. This also had only a short term beneficial effect. The DOD was reduced to 60 percent at cycle 1360 . This substantially improved the cell performance. At cycle 2220 the recharge ratio was increased from 1.07 to 1.10 in an attempt to improve cell performance. This had a limited beneficial effect. At cycle 2470 the end of discharge voltage was $1.11 \mathrm{~V}$. The cycle life test ( 60 percent DOD) will be continued until fallure. Then the $00 D$ will be reduced to 40 percent and the cycling continued to fallure. The cells will undergo teardown and faflure analysis.

\section{CONCLUDING REMARKS}

The effect of storage and LEO cycling on the performance of Yardney manufacturing technology $50 \mathrm{~A}-\mathrm{hr}$ space weight IPV nickel-hydrogen cells was investigated. No performance degradation was observed due to 1 yr storage (hydrogen precharge $14.5 \mathrm{psia}$, terminais shorted). On the average the cycle life was 741 cycles at 80 percent DOD. This cycle life is inadequate for most LEO applications requiring a long cycle life at deep depths of discharge. The DOD was reduced to 60 percent and the test continued. At this 000 the cell performance was improved. The cells have accumulated 2423 cycles $(80+60$ percent $D 0 D)$ on the average and are performing satisfactorily in the continuing test.

\section{REFERENCES}

1. McDermott, J.K., "Low-Earth-Orbit Testing of Nicke1-Hydrogen Cells," Advancing Toward Technology Breakout in Energy Conversion, 21 st IECEC Proceedings, Vol. 3, AIAA, New York, 1986, pp. 1516-1520.

2. "Manufacturing Technology for Nickel Hydrogen Cells, "Yardney Battery Division, Yardney Electric Corp., AFWAL-F-33615-80-C-5036, 1982.

3. Gross, S., "Review of Electrochemical Impregnation for Nickel Cadmium Cells," JPL-953984, 1977. (Also, NASA CR-155155).

TABLE 1. - CAPACITY OF YARDNEY MANUFACTURING TECHNOLOGY

SPACE WEIGHT IPV NICKEL-HYDROGEN CELLS

AFTER I YEAR STORAGE

\begin{tabular}{|c|c|c|c|c|}
\hline Ce11 & $\begin{array}{c}\text { Capacity, } \\
\text { A-hra }\end{array}$ & $\begin{array}{c}V_{\text {EO0 }} \\
\text { Vb }\end{array}$ & $\begin{array}{c}\text { Oischarge } \\
\text { current, } \\
A\end{array}$ & $\begin{array}{c}\text { Temperature, } \\
{ }^{\circ} \mathrm{C}\end{array}$ \\
\hline 1 & 52.5 & 1.0 & 68.5 & 23 \\
2 & 53.7 & 1.0 & 68.5 & 23 \\
3 & 53.0 & 1.0 & 68.5 & 23 \\
\hline
\end{tabular}

a After charge $16 \mathrm{hr}$ at $\mathrm{C} / 10$ (5 A)

b $V_{E O D} \equiv$ End of discharge voltage (V) 
TABLE 2. - SUMMARY OF CYCLE LIFE TEST RESULTS YARDNEY MANUFACTURING TECHNOLOGY 50 A-hr SPACE WEIGHT IPV NICKEL-HYDROGEN CELLS - 80 PERCENT DOD LEO CYCLES

\begin{tabular}{|c|c|c|c|}
\hline $\mathrm{Cell}$ & $\begin{array}{l}\text { Cycle at } \\
\text { fallure }\end{array}$ & $\begin{array}{l}\text { Failure } \\
\text { mode }\end{array}$ & Status \\
\hline 1 & 737 & $\begin{array}{l}\text { Degradation of } \\
V_{\text {EOD }} \text { to } 1.0 \mathrm{~V}\end{array}$ & $\begin{array}{l}\text { DOD reduced to } \\
60 \text { percent, cycling } \\
\text { continuing }\end{array}$ \\
\hline 2 & 750 & $\begin{array}{l}\text { Degradation of } \\
V_{E O D} \text { to } 1.0 \mathrm{~V}\end{array}$ & $\begin{array}{l}\text { D00 reduced to } \\
60 \text { percent, cyciling } \\
\text { continuing }\end{array}$ \\
\hline 3 & 735 & $\begin{array}{l}\text { Degradation of } \\
V_{E O D} \text { to } 1.0 \mathrm{~V}\end{array}$ & $\begin{array}{l}\text { DoD reduced to } \\
60 \text { percent, cycling } \\
\text { continuing }\end{array}$ \\
\hline
\end{tabular}

TABLE 3. - SUMMARY OF CYCLE LIFE TEST RESULTS YARDNEY MANUFACTURING TECHNOLOGY $50 \mathrm{~A}-\mathrm{hr}$ SPACE WEIGHT IPV $\mathrm{NIH}_{2}$ CELLS - 80 PLUS 60 PERCENT DOD LEO CYCLES

\begin{tabular}{|c|c|c|c|}
\hline Cel1 & Cycie & $v_{E 00}$ & Status \\
& & $v^{a}$ & \\
2 & 2331 & 1.11 & Test continuing \\
3 & 2423 & 1.11 & Test continuing \\
\hline
\end{tabular}

${ }^{a} V_{E O D} \equiv$ End of 35 min discharge voltage, $v$ 
ORIGINAL PAGE IS

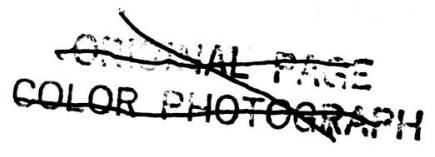

OF POOR QUALITY

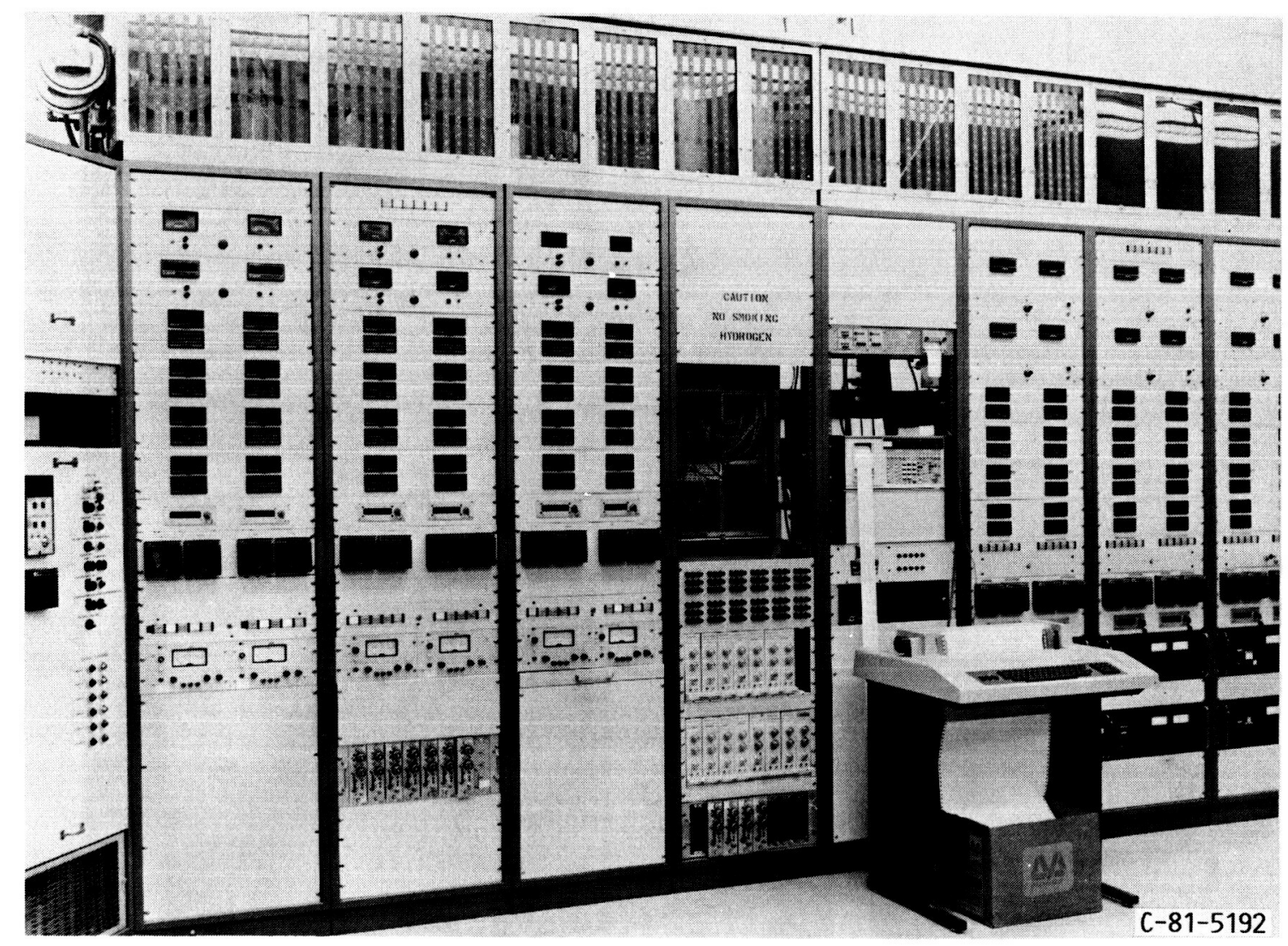

FIGURE 1. - NICKEL-HYDROGEN CELL TEST FACILITY. 


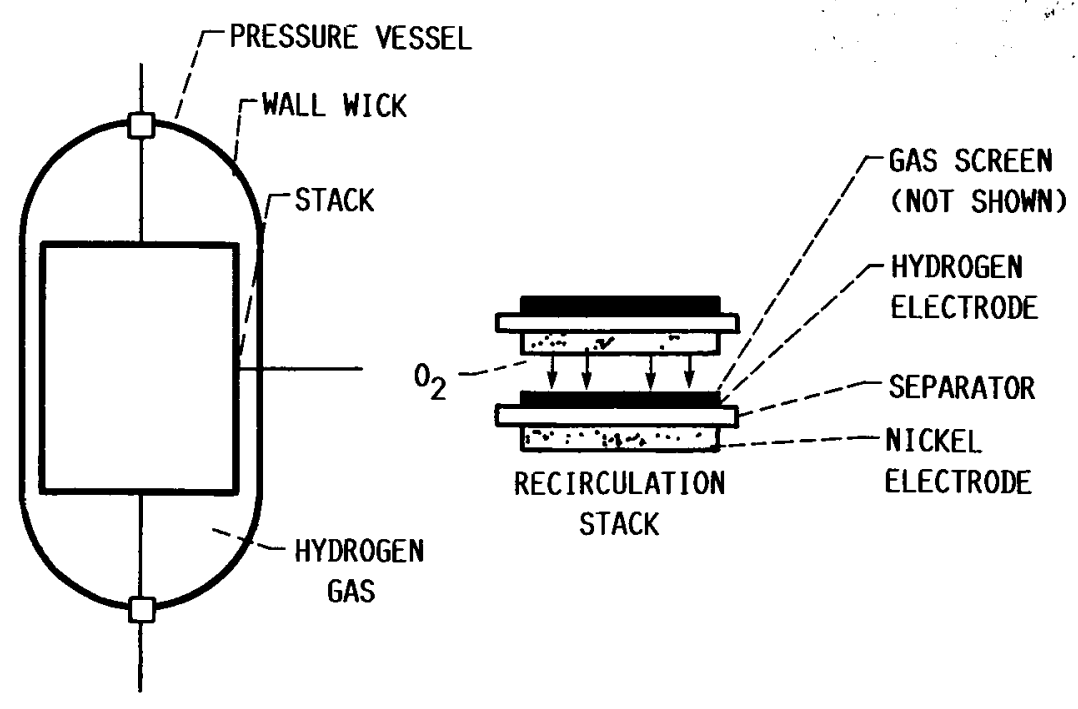

FIGURE 2. - ILLUSTRATION OF YARDNEY MANUFACTURING TECHNOLOGY INDIVIDUAL PRESSURE VESSEL NICKEL-HYDROGEN CELL.

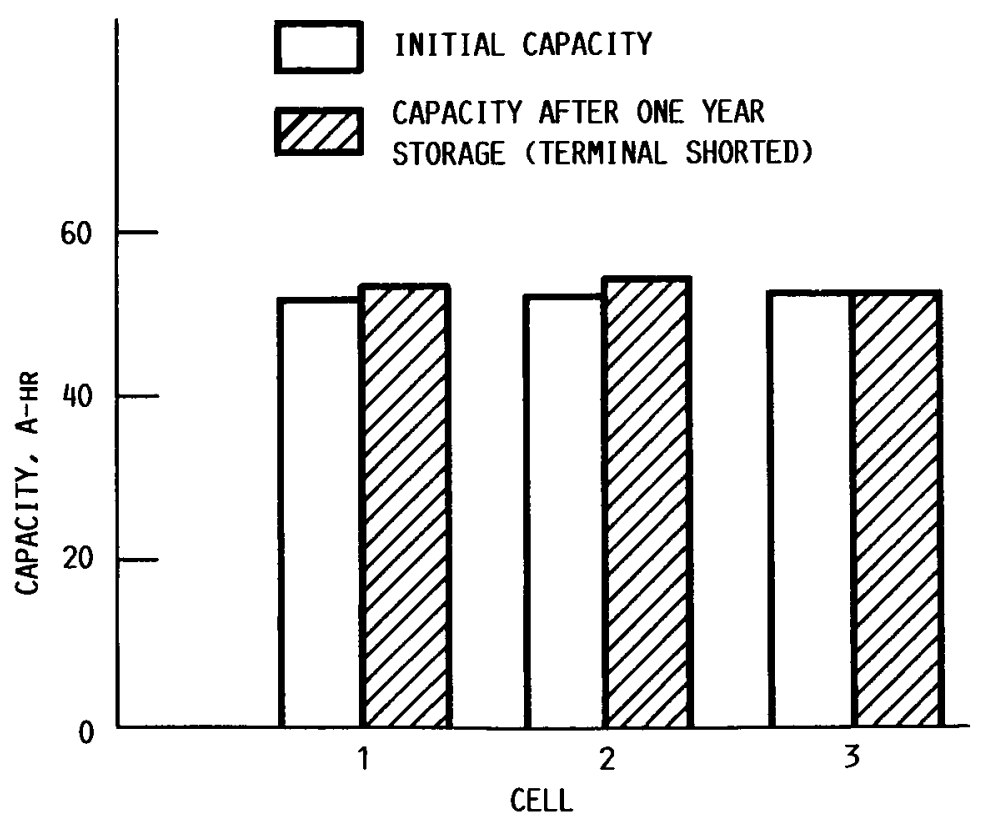

FIGURE 3. - EFFECT OF STORAGE ON CAPACITY OF 5OAH YARDNEY SPACE WEIGHT IPV $\mathrm{NI}_{1} / \mathrm{H}_{2}$ CELLS. 

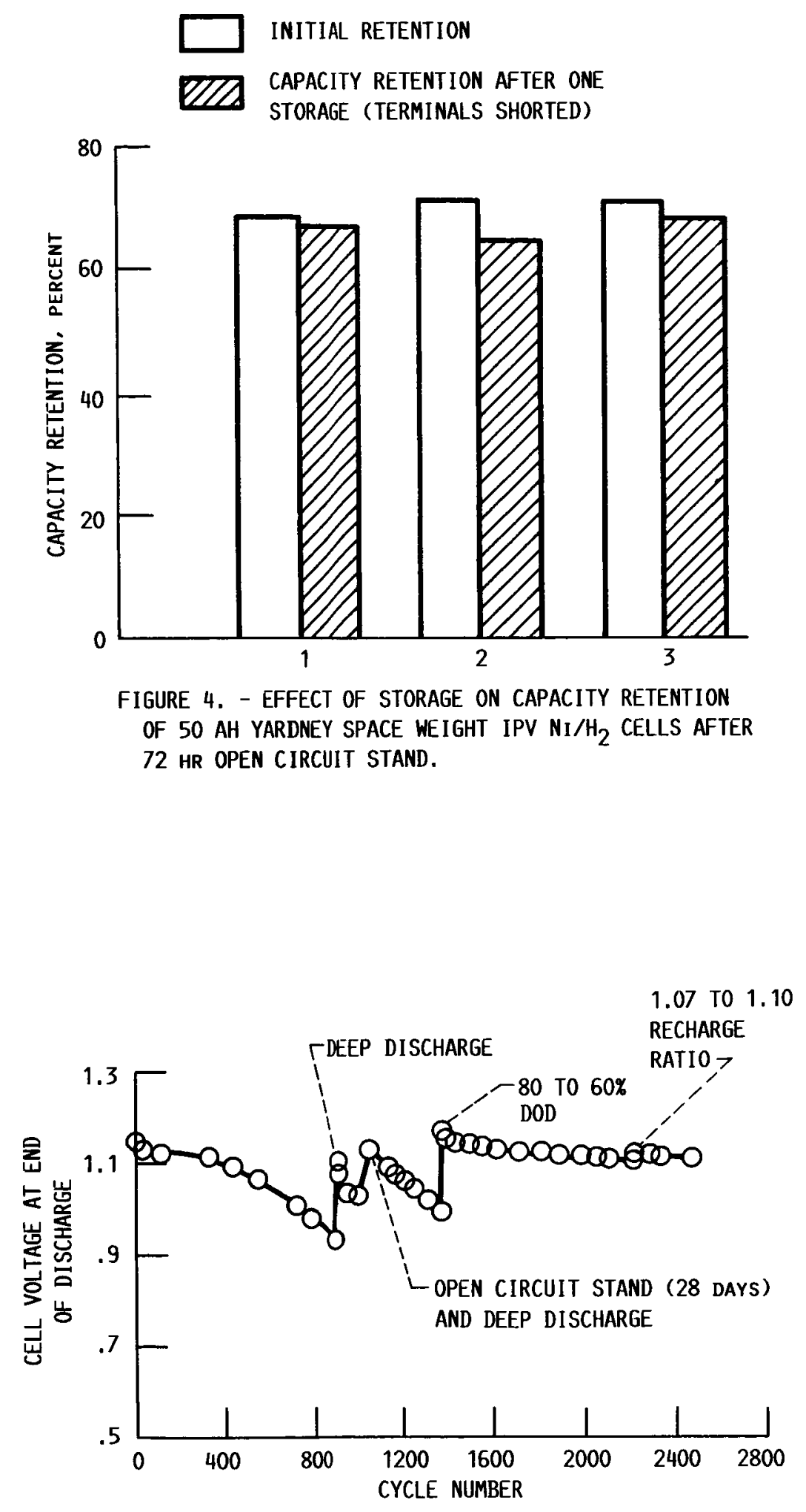

FIGURE 5. - EFFECT OF CHARGE/DISCHARGE CYCLING AND RECONDITIONING ON END OF DISCHARGE VOLTAGE OF A REPRESENTATIVE 50 AH YARDNEY MANTECH IPV $\mathrm{N}_{1} / \mathrm{H}_{2}$ CELL. 


\begin{tabular}{|c|c|c|}
\hline $\begin{array}{ll}\text { 1. Report No. } & \text { NASA TM-89883 } \\
\text { AIAA-87-9318 }\end{array}$ & 2. Government Accession No. & 3. Recipient's Catalog No. \\
\hline \multicolumn{2}{|l|}{ 4. Title and Subtitle } & 5. Report Date \\
\hline \multicolumn{2}{|c|}{$\begin{array}{l}\text { Effect of Storage and LEO Cycling on Manufacturing } \\
\text { Technology IPV Nicke1-Hydrogen Cellis }\end{array}$} & $\begin{array}{l}\text { 6. Performing Organization Code } \\
506-41-21\end{array}$ \\
\hline \multirow{2}{*}{\multicolumn{2}{|c|}{$\begin{array}{l}\text { 7. Author(s) } \\
\text { John J. Smithrick }\end{array}$}} & $\begin{array}{l}\text { 8. Performing Organization Report No. } \\
\text { E-3566 }\end{array}$ \\
\hline & & 10. Work Unit No. \\
\hline \multicolumn{2}{|c|}{ 9. Performing Organization Name and Address } & \\
\hline \multicolumn{2}{|c|}{$\begin{array}{l}\text { National Aeronautics and Space Administration } \\
\text { Lewis Research Center } \\
\text { Cleveland, Ohio } 44135\end{array}$} & \begin{tabular}{|l} 
\\
3 Type of Renort and Perind Covered
\end{tabular} \\
\hline \multicolumn{2}{|l|}{ 12. Spunsoring Agency Name and Address } & Technical Memorandum \\
\hline \multicolumn{2}{|c|}{$\begin{array}{l}\text { National Aeronautics and Space Administration } \\
\text { Washington, D.C. } 20546\end{array}$} & 14. Sponsoring Agency Code \\
\hline \multicolumn{3}{|c|}{$\begin{array}{l}\text { Prepared for the 22nd Intersociety Energy Conversion Engineering Conference, } \\
\text { cosponsored by the AIAA, ANS, ASME, SAE, IEEE, ACS, and AIChE, Philadelphia, } \\
\text { Pennsylvania, August 10-14, 1987. }\end{array}$} \\
\hline \multicolumn{3}{|c|}{$\begin{array}{l}\text { Yardney Manufacturing Technology (MANTECH) } 50 \text { A-hr space weight individual } \\
\text { pressure vessel nickel-hydrogen cells were evaluated. This consisted of inves- } \\
\text { tigating: ( } 1 \text { ) the effect of storage and (2) charge/discharge cycling on cell } \\
\text { performance. For the storage test the cells were precharged with hydrogen, by } \\
\text { the manufacturer, to a pressure of } 14.5 \mathrm{psia} \text {. After undergoing activation and } \\
\text { acceptance tests, the cells were discharged at C/10 rate ( } 5 \text { A) to } 0.1 \mathrm{~V} \text { or less. } \\
\text { The terminals were then shorted. The cells were shipped to NASA Lewis Research } \\
\text { Center where they were stored at room temperature in the shorted condition for } \\
1 \text { yr. After storage, the acceptance tests were repeated at NASA Lewis. A com- } \\
\text { parison of test results indicate no significant degradation in electrical per- } \\
\text { formance due to } 1 \text { yr storage. For the cycle life test the regime was a } 90 \text { min } \\
\text { low earth orbit at deep depths of discharge (80 and } 60 \text { percent). At the } 80 \text { per- } \\
\text { cent DoD the three cells failed on the average at cycle } 741 \text {. Failure for this } \\
\text { test was defined to occur when the cell voltage degraded to } 1 \mathrm{~V} \text { prior to com- } \\
\text { pletion of the } 35 \text { min discharge. The DoD was reduced to } 60 \text { percent. The cycle } \\
\text { life test was continued. }\end{array}$} \\
\hline \multicolumn{3}{|l|}{ 17. Key Words (Suggested by Author(s)) } \\
\hline $\begin{array}{l}\text { Batteries } \\
\text { Nickel-hydrogen cells } \\
\text { Energy storage }\end{array}$ & $\begin{array}{l}\text { Unc lass } \\
\text { STAR Ca }\end{array}$ & $\begin{array}{l}\text { d }- \text { unlimited } \\
\text { ry } 44\end{array}$ \\
\hline $\begin{array}{l}\text { 19. Security Classif. (of this report) } \\
\text { Unclass if ied }\end{array}$ & $\begin{array}{l}\text { 20. Security Classif. (of this page) } \\
\text { Unc las s if ied }\end{array}$ & \begin{tabular}{|c|c|} 
21. No. of pages & 22. Price* \\
9 & $\mathrm{AO2}$
\end{tabular} \\
\hline
\end{tabular}

*For sale by the National Technical Information Service, Springfield, Virginia 22161 